\title{
ZAMEJSKA KOROŠKA, VODNIKI LJUBLJANSKEGA GEOGRAFSKEGA DRUŠTVA
}

\author{
Andrej Bandelj, Jože Mihelič, Jernej Zupan- \\ čič: Zamejska Koroška. Vodniki Ljubljan- \\ skega geografskega društva, ZRC SAZU, \\ 213 str. Ljubljana, 2016
}

V letu 2016 smo se lahko razveselili nove publikacije Ljubljanskega geografskega društva (LGD). Gre za geografski vodnik po Zamejski Koroški, ki je nastal kot rezultat eno- in dvodnevnih ekskurzij po Sloveniji in zadnja leta že kar tradicionalno, predvsem po njeni neposredni, zamejski okolici. Z njimi LGD sistematično, drugo za drugim odkriva

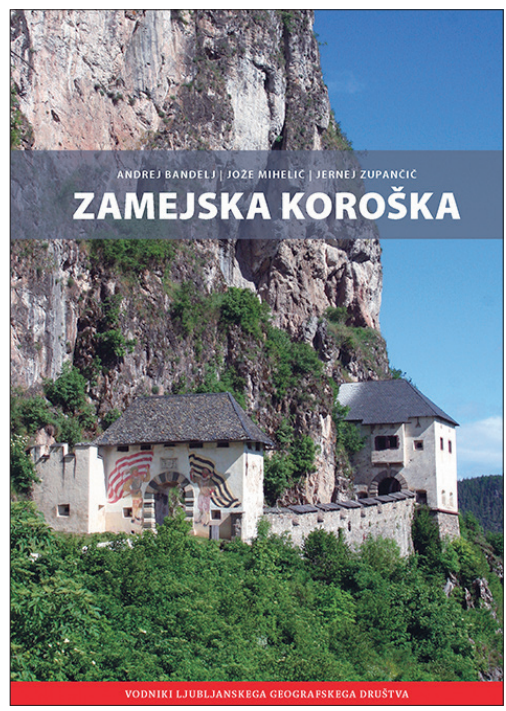
tančice našega narodnostnega ozemlja, ki nam je prostorsko tako blizu, kljub temu pa marsikdaj zelo oddaljeno, očem skrito in slabše poznano. Publikacija je plod dveh geografov (Andreja Bandlja in Jerneja Zupančiča) in profesorja športne vzgoje in naravovarstvenika Jožeta Miheliča. Vodnik na začetku krasi uvodnik urednika Draga Kladnika. V vodniku je na ustaljen način predstavljenih devet ekskurzij, ki so jih avtorji izpeljali med aprilom 2013 in septembrom 2015. Težišče predstavljenih ekskurzij je v severozahodnem delu slovenskega zamejskega ozemlja, ki se postavlja z izjemno bogato naravno, zanimivo zgodovinsko in pestro kulturno dediščino. Gre za ozemlje, ki smo ga Slovenci s plebiscitom 1920 (verjetno) dokončno izgubili in je od takrat naprej pod pritiskom ponemčevanja. Devet poglavij v vodniku vključuje: Ziljsko dolino, Beljak in okoliška jezera, Karavanke in Rož, Celovec in Gosposvetsko polje, Južna pobočja Svinške planine in Velikovško čezdravje, Podjuno, Labotsko dolino, Zgodovinske kraje severne Koroške in Pogorje Nockberge z biosfernim parkom.

Prva ekskurzija obravnava eno najdaljših alpskih dolin reke Zilje, ki poteka ob periadriatskem šivu, med Karnijskimi Alpami na jugu in Ziljskimi na severu. Med pomembnejšimi postajami lahko izpostavimo Dobrač s silovitim podorom, etnološki biser Bistrico na Zilji, športno zibelko Zahomec ter turističnega velikana Mokrine. Na celotnem območju lahko zasledimo slovenstvo, čeprav ponekod le še v krajevnih imenih. Močan pečat je pokrajini dala tudi prva svetovna vojna, saj jo je za vedno spremenila. Drugo ekskurzijo je prav tako vodil Andrej Bandelj. Obiskali so strateško pomembno prometno vozlišče Beljak ter njegovo okolico, polno ledeniških jezer, ki so temelj tamkajšnjega turizma. Tretjo ekskurzijo je pripravil Jernej Zupančič, s katero se je osredotočil na same Karavanke in Rož. Območje predstavlja eno od jeder poselitve Slovencev na avstrijskem Koroškem. Z ekskurzijo odkrivamo naravne vrednote (soteska Čepa), zgodovino (nekdanje rudarstvo v Železni Kapli), gospodarstvo in turizem (zdravilišča) pokrajine, kjer si slovenska narodna skupnost že vsaj stoletje in pol prizadeva ne le za miniaturno etnično preživetje, ampak 
tudi prispeva pomemben delež v zakladnico slovenskega jezika in kulture. Naslednjih pet ekskurzij je ponovno pripravil Andrej Bandelj. V obratni smeri urinega kazalca se lahko popeljemo najprej v Celovec in na zgodovinsko pomembno Gosposvetsko polje. Območje ni veliko, zato se ekskurzija osredotoča na Celovec in njegovo vlogo, turistično pomembno bližnje Vrbsko jezero. Velik del je, razumljivo, posvečen zgodovinskemu pregledu od antike do danes. Peta ekskurzija nadaljuje pot od Celovca proti južnim pobočjem Svinške planine in se zaključi v Velikovcu. Tudi pri tej ekskurziji je močno v ospredju plebiscitna problematika ter pomen Drave kot mejne reke. Če le omenimo, da so Avstrijci »najbolj sončno vas Avstrije« (Djekše) razglasili za eno najprivlačnejših v vsej državi, je ekskurzija vredna ponovitve.

Podjuna je tisti del zamejske Koroške, ki je s Slovenijo najbolje povezan, saj od matične države ni ločen s težko prehodno naravnogeografsko oviro, kakršno na preostalem delu državne meje predstavljajo Karavanke. Podjuno je po mnenju avtorja vredno obiskati iz več razlogov. Gre namreč za območje velikih naravnih lepot, ki so posledica ledeniškega delovanja na vzhodnem robu Celovške kotline. Poleg tega je bila zaradi svoje lege in ugodnih naravnogeografskih razmer že zelo zgodaj poseljena, obenem ima območje tudi velik hidroenergetski potencial. Sedma ekskurzija nas popelje v svojevrstno in od ostalih delov Koroške precej drugačno Labotsko dolino. Dolina zaradi odprtosti predstavlja toplotni otok, zato bomo v njej našli vinograde in nasade špargljev. Nekateri ji pravijo »Koroški raj«, ki ga mnogi obiščejo kar s kolesi in si obenem lahko naberejo moči v številnih zdraviliščih. Zaradi večstoletne pripadnosti Salzburški nadškofiji in nadškofiji iz bavarskega Bamberga ima Labotska dolina velik zgodovinski pomen tudi za Slovenijo. Tudi osma ekskurzija je precej zgodovinsko naravnana, saj obišče pomembne kraje, kot so grad Ostrovica, Šentvid ob Glini, Breže, Krka in Straßburg, ki so bili v srednjem veku nosilci moči in razvoja te dežele. O njihovi nekdanji slavi priča predvsem bogata arhitekturna dediščina. Zadnja ekskurzija od ostalih nekoliko odstopa. Pogorje in biosferni park Nockberge leži precej onstran severnega roba slovenskega narodnostnega ozemlja. Obenem kopasti vrhovi bolj spominjajo na avstrijske pokrajine, kot pa tipične zašiljene »slovenske Alpe«. Kamninska podlaga je botrovala razvoju rudarstva, v naravi pa veliki pestrosti in bogastvu rastlinstva ter živalstva. Ekskurzijo je pripravil naravovarstvenik Jože Mihelič, ki po izobrazbi ni geograf, kar pa ne zmanjšuje pestrosti predstavljenih geografskih vsebin.

Vodnik nas ne razočara niti po privlačnosti izbranih ekskurzij niti po vsebinski plati, še manj po oblikovni in slikovni pestrosti. Publikacija je polna čudovitih avtorskih posnetkov, ki kar vabijo, da bi se bralec podal na potep po Zamejski Koroški. Tisti, ki vodnike redno prebirate (in tudi uporabljate), vsebinsko zasnovo poznate in tudi tokrat ni večjih odstopanj. »Novinci« boste mogoče pogrešali predvsem fizičnogeografske vsebine, pa vendar menim, da nihče ne bo kaj prida prikrajšan. Prej nasprotno: pričujoči vodnik je najbolj obsežen izmed vseh do sedaj izdanih slovenskih vodnikov.

LGD je eno redkih društev, ki s pomočjo mešanice strokovnih ter ljubiteljskih, predvsem pa prostovoljnih geografskih in negeografskih sodelavcev, pridno izdaja vodnike, ki dosegajo zavidljivo, na eni strani privlačno in poljudno raven ter na drugi strani primerno strokovno raven. Na tak način dokaj spretno krmarijo med dostopnostjo za širšo publiko 
in specialno geografsko uporabnostjo. Z leti se je vodnikov nabralo že kar precej. Zamejska Slovenija je že... katera po vrsti? Težko reči, katera. Če štejemo le tiste, ki so nastale kot plod eno- in dvodnevnih ekskurzij po Sloveniji in njeni bližnji okolici, je to že deseta. Če štejemo vse, pa je to že kar legendarna 30. izdaja. To pomeni v povprečju več kot ena publikacija na leto, odkar je ne tako davnega leta 1991 izšel vodnik po Portugalski. Zaradi poznane problematike društev tako tujih, prvomajskih ekskurzij LGD ni več in posledično tudi vodnikov ne bo. Kritike »slovenskih« vodnikov tudi niso osamljene. Resda včasih malo upravičene, pogosto pa vseeno podane s premalo razumevanja za vloženi trud in delo, ki sta potrebna, da pridemo do takšne prijetne, na videz drobne in preproste knjižice.

S strahom se lahko upravičeno sprašujemo: »Koliko časa še?« Upam, da še dolgo. Prosim, še.

Blaž Repe 